\title{
Flavobacterium psychrophilum associated with septicaemia and necrotic myositis in Atlantic salmon Salmo salar: a case report
}

\author{
Hanne Nilsen $^{1, *}$, Renate Johansen ${ }^{2}$, Duncan John Colquhoun ${ }^{2}$, Inge Kaada ${ }^{3}$, \\ Kirsten Bottolfsen ${ }^{1}$, Øyvind Vågnes ${ }^{1}$, Anne Berit Olsen ${ }^{1}$ \\ ${ }^{1}$ Norwegian Veterinary Institute Bergen, PO Box 1263 Sentrum, 5811 Bergen, Norway \\ ${ }^{2}$ Norwegian Veterinary Institute Oslo, PO Box 750 Sentrum, 0106 Oslo, Norway \\ ${ }^{3}$ VestVet A/S, Firdaveien 6, 6800 Førde, Norway
}

\begin{abstract}
We describe the first case from Norway of increased mortality in Atlantic salmon Salmo salar (L.), with septicaemia and necrotic myositis, associated with infection by Flavobacterium psychrophilum. The outbreak occurred in smolt of 60 to $100 \mathrm{~g}$ in fresh water on a landbased farm in Western Norway during winter 2008-2009. The water temperature was $<5^{\circ} \mathrm{C}$ and the accumulated mortality was $7.0 \%$. Necropsy of dead and moribund fish revealed a swollen dark spleen, pale liver, serohaemorrhagic ascites and haemorrhage in the abdominal fat and muscle. F. psychrophilum was isolated from the kidney and spleen of diseased fish. Muscle biopsy revealed the presence of long filamentous rods in necrotic areas of skeletal muscle. Immunohistochemistry was positive for F. psychrophilum. Identification of cultured isolates as F. psychrophilum was confirmed using phenotypic testing and sequencing of the 16S rRNA gene. Analysis by allele-specific polymerase chain reaction (allele-specific PCR) indicated that 2 different genotypes of the bacterium were present in the outbreak.
\end{abstract}

KEY WORDS: Flavobacterium psychrophilum • Atlantic salmon · Necrotic myositis · Septicaemia 16S rRNA allele

Resale or republication not permitted without written consent of the publisher

\section{INTRODUCTION}

Flavobacterium psychrophilum (formerly Cytophaga psychrophila; Flexibacter psychrophilus) (Bernardet et al. 1996) is well recognized as the causative agent of rainbow trout fry syndrome (RTFS) and bacterial cold water disease (BCWD), diseases which cause substantial losses in the salmonid industry worldwide. Disease associated with F. psychrophilum was originally described in the USA from rainbow trout Oncorhynchus mykiss (Walbaum) and juvenile coho salmon Oncorhynchus kisutch (Walbaum) (Davis 1946, Borg 1948, 1960). Since then, F. psychrophilum has been associated with diseases that include fin rot, peduncle disease and systemic disease in both salmonids and non-salmonid freshwater species - e.g. eel Anguilla anguilla (L.) and cyprinids, i.e. common carp Cyprinus carpio (L.), crucian carp Carassius carassius (L.) and tench Tinca tinca (L.) (for a review see Nematollahi et al. 2003a).

Flavobacterium psychrophilum has also been recognized as the cause of necrotic myositis and cephalic osteochondritis in rainbow trout (Lumsden et al. 1996, Ostland et al. 1997).

In Norwegian aquaculture - until the recent epizootic of RTFS/BCWD with its associated high losses in rainbow trout (Nilsen et al. 2011) - isolations of Flavobacterium psychrophilum have been associated almost exclusively with occasional cases of fin rot and ulceration in Atlantic salmon Salmo salar (L.) and 
brown trout Salmo trutta (L.) (Johansen et al. 2009). On a worldwide basis, although isolations of F. psychrophilum from Atlantic salmon are not uncommon, reports of systemic infections are scarce, lending support to observations that this species of fish is less susceptible to this disease (Holt et al. 1993, Schmidtke \& Carson 1995, Ekman et al. 1999, Valdebenito \& Avendaño-Herrera 2009). To the best of our knowledge the present paper describes the first case in which F. psychrophilum has been associated with septicaemia and necrotic myositis in Atlantic salmon in Norway.

\section{MATERIALS AND METHODS}

Case history. The disease was first detected in late autumn 2008 in a group of 82000 Atlantic salmon smolts of 60 to $100 \mathrm{~g}$ in a land-based unit in Western Norway. The water temperature was $<5^{\circ} \mathrm{C}$. Owing to limited resources of fresh water, UV-treated sea water was used to buffer the fresh water, resulting in salinity of approximately 2 to $3 \%$.

The fry were hatched in December 2007 at a freshwater site located in the same region; they were moved to the unit at the beginning of January 2008. Vaccination against infectious pancreatic necrosis was performed in April (AquaVac ${ }^{\circledR}$ IPN Oral), and against furunculosis, vibriosis, coldwater vibriosis, Moritella viscosa infection and infectious pancreatic necrosis in August (Alphaject 6-2 ${ }^{\circledR}$, polyvalent i.p. vaccine). Despite completion of smoltification by October 2008, transfer of the smolts to sea water was delayed until the spring of 2009. Owing to this delay, the fish were revaccinated in November and December with a polyvalent i.p. vaccine against pancreatic disease (Norvax ${ }^{\circledR}$ Compact PD) at 1.5 to $2{ }^{\circ} \mathrm{C}$. The mortality started to increase at the end of November, 2008, and remained elevated through December 2008 and January 2009. Daily losses peaked at $0.5 \%$. In late January 2009 treatment with oxolinic acid (Oxolinsyre, Skretting) $5 \mathrm{mg} \mathrm{kg}^{-1}$ (2 and $3 \mathrm{~mm}$ pellets) was initiated. Despite a drop in mortality after $17 \mathrm{~d}$ to $0.15 \%$ the fish were subsequently destroyed.

Fish sampling. During a period of $8 \mathrm{wk}$, from early December 2008 to late January 2009, a total of 21 moribund fish were sampled on 4 different occasions. Seven fish were collected by the fish health practitioner at the beginning of the outbreak and submitted to the laboratory as formalin-fixed samples. The remainder were transported, chilled, to the laboratory for examination.

Histopathology. Tissue samples from gill, heart, liver, pyloric caeca with pancreatic tissue, spleen, kidney and skeletal muscle were taken from all the fish, and eye and brain tissues were taken from 4 and 5 fish, respectively. These tissues were fixed in 10\% phosphate-buffered formalin ( $\mathrm{pH} 7.2$ to 7.4) for histopathological studies. The organs were separately embedded in paraffin, and sections were stained with haematoxylin and eosin (H\&E). Sections from skeletal muscle were also stained with May Grünwald Giemsa, and a selection of sections from kidney were stained with von Kossa (Prophet et al. 1994).

Immunohistochemistry was performed on sections from muscle, kidney, heart, spleen, liver, brain and eye. An enzyme-labelled streptavidin procedure, with fast red as chromogen and polyclonal rabbit antiserum against Flavobacterium psychrophilum serotype Th diluted 1:5000 in 0.05 M Tris buffer, pH 7.6 was used (Evensen \& Lorenzen 1996). Sections known to be infected with $F$. psychrophilum were used as positive controls. The anti-F. psychrophilum serum was replaced with non-specific rabbit serum in negative controls.

Isolation of bacteria. Samples from kidney and spleen from all 14 fish sampled and muscle tissues from 4 fish were streaked onto 2 types of medium: (1) Anacker \& Ordal's medium (Anacker \& Ordal 1959) with $1.1 \%$ agar (AOA), and (2) heart infusion agar containing $5 \%$ ovine blood (BA); the plates were incubated at $15^{\circ} \mathrm{C}(\mathrm{AOA})$ and $22^{\circ} \mathrm{C}(\mathrm{BA})$ and were examined after 2 and $4 \mathrm{~d}$. Incubation and observation were extended by a further $10 \mathrm{~d}$.

Physiological and biochemical characterisation. For all tests, cells from cultures on AOA incubated for $3 \mathrm{~d}$ at $15^{\circ} \mathrm{C}$ were used. Plates for determining the temperature-growth range were observed for initial growth after $4 \mathrm{~d}$ and then every second day for a further $7 \mathrm{~d}$. Bacterial isolates were phenotypically examined as described by Bernardet et al. (2002): catalase and cytochrome oxidase activities, absorption of Congo red, and the presence of cell-wallassociated flexirubin-type pigment. API ZYM (bioMérieux ${ }^{\circledR}$ ) tests were performed according to the manufacturer's instructions, the strips being incubated at $15^{\circ} \mathrm{C}$ for $24 \mathrm{~h}$.

Test tubes containing $2.0 \mathrm{ml}$ of AOA medium supplemented with $12 \%$ gelatine $\left(\right.$ Difco $^{\mathrm{TM}}$ Nutrient Gelatin) were stab-inoculated, incubated at $15^{\circ} \mathrm{C}$, and read after 4 and $11 \mathrm{~d}$. Liquification, or partial liquification, of the medium in the tubes indicated a positive result for gelatin hydrolysis. The test was done in duplicate.

Agar plates (AOA) supplemented with 0.5 or $0.05 \%$ elastin (derived from bovine neck ligament; 
Sigma) were streak-inoculated, incubated at $15^{\circ} \mathrm{C}$, and read initially after $4 \mathrm{~d}$ and again after 10 or $11 \mathrm{~d}$. Clearing of the cloudy medium around the colony was recorded as a positive result for elastin hydrolysis. The test was done in duplicate.

The type strain, Flavobacterium psychrophilum NCIMB 1947T (ATCC 49418T), and strain CSF 25993 were included for comparative purposes in all analyses.

Susceptibility to antibiotics. Antibiotic sensitivity was evaluated for 4 isolates, and for NCIMB $1947 \mathrm{~T}$ and CSF 259-93, by the disc diffusion method (Sigma) on AOA. For one representative isolate the test was repeated in triplicate on AOA and on dilute Mueller-Hinton $(\mathrm{MH})$ agar supplemented with $5 \%$ faetal calf serum (Clinical and Laboratory Standards Institute (CLSI) (2006)) for comparison. Discs containing trimethoprim + sulfamethoxazole $(5.2+240 \mu \mathrm{g}$, respectively), flumequin $30 \mu \mathrm{g}$, oxolinic acid $10 \mu \mathrm{g}$, tetracycline $80 \mu \mathrm{g}$, florfenicol $30 \mu \mathrm{g}$ (Neo-Sensitabs, Rosco ${ }^{\circledR}$ ) were used. The inoculated plates were incubated at $15^{\circ} \mathrm{C}$ for 3 to $6 \mathrm{~d}$. Aeromonas salmonicida subsp. salmonicida ATCC 14174 was included in these tests as a quality control.

16S rRNA gene sequence analysis. Nearly-complete 16S rRNA gene sequences were obtained from isolates NVIB 2008-50-3055-4, NVIB 2008-503055-6 and NVIB 2009-50-154-14 using the universal primers described by Weisburg et al. (1991). Sequencing (in 2 directions) was performed with the DYEnamic $^{\mathrm{TM}}$ ET dye terminator cycle sequencing kit and a MEGABACE 1000 capillary sequencer (Amersham Biosciences). The sequences were analysed using the basic local alignment search tool (BLAST).

Allele-specific PCR assay. Our isolates of Flavobacterium psychrophilum were subjected to $16 \mathrm{~S}$ rRNA allele-specific PCR using primers for amplification of CSF 259-93 and ATCC 49418 16S rRNA alleles as described by Ramsrud et al. (2007). Strains from rainbow trout, trout, and Atlantic salmon previously isolated in Norway, were included for comparative purposes, as were NCIMB $1947 \mathrm{~T}$ (ATCC 49418T) and CSF 259-93. For the origin and year of isolation of strains see Table 4.

The PCR reaction included $5 \times$ reaction buffer (Go Taq Green Master Mix, Promega) supplemented with $2.0 \mathrm{mM} \mathrm{MgCl}, 0.15 \mathrm{mM}$ dNTPs, $0.25 \mathrm{mM}$ of each primer, 0.1 units of Taq DNA polymerase (Go Taq Promega) and ca. $1 \mathrm{ng} \mathrm{\mu l}^{-1}$ of bacterial DNA.

PCR cycling conditions were as follows: predenaturation at $94^{\circ} \mathrm{C}$ for $5 \mathrm{~min} ; 24$ cycles of denaturation at $94^{\circ} \mathrm{C}$ for $30 \mathrm{~s}$, annealing at $55^{\circ} \mathrm{C}$ for $30 \mathrm{~s}$ and exten- sion at $72^{\circ} \mathrm{C}$ for $1 \mathrm{~min} ; 12$ cycles of denaturation at $94^{\circ} \mathrm{C}$ for $30 \mathrm{~s}$, annealing at $45^{\circ} \mathrm{C}$ for $30 \mathrm{~s}$ and extension at $72^{\circ} \mathrm{C}$ for $2 \mathrm{~min}$ with a final cycle at $72^{\circ} \mathrm{C}$ for $10 \mathrm{~min}$. The PCR products $(5 \mu \mathrm{l})$, and $1.5 \mu \mathrm{l}$ tracking dye, were mixed and electrophoresed on $1.0 \%$ agarose gel at $75 \mathrm{~V}$ for $90 \mathrm{~min}$.

Virology. Kidneys from 8 fish were placed in RNAlater $^{\circledR}$ (Ambion) and transported in Eagle's minimum essential medium (EMEM), pH 7.6, supplemented with $10 \%$ newborn calf serum and $100 \mu \mathrm{g}$ $\mathrm{ml}^{-1}$ gentamicin. Samples in RNAlater ${ }^{\circledR}$ were subjected to a quantitative reverse-transcriptase polymerase chain reaction (qRT-PCR) assay for viral haemorrhagic septicaemia virus (VHSV), according to Matejusova et al. (2008). An RT-PCR for infectious haematopoietic necrosis virus (IHNV) was performed using the forward primer IHNNC-F1 (5'-ACC TTC GCA GAT CCC AAC AAC AA-3') (Manual of diagnostic tests for aquatic animals 2003; http://www. oie.int) and the reverse primer (designed in-house) IHNNC-R2 (5'-GCG CAC AGT GCC TTG GCT-3'). Cell culturing was done as described by Lorenzen et al. (1999).

\section{RESULTS}

\section{Clinical findings and gross pathology}

Although total daily losses were low, morbidity was high, with a large proportion of the fish displaying lethargic swimming behaviour near the water surface or resting on the bottom of the tanks. External macroscopic findings included moderate exophthalmia, swelling of the caudal peduncle and occasional haemorrhagic skin lesions with partial loss of epidermis.

Petecchiae on the abdomen were noted in a few fish. Necropsy revealed a swollen dark spleen, uneven discolored liver, serohaemorrhagic ascites and haemorrhage in the abdominal fat. In skeletal muscle, extensive petecchiation and large haemorrhagic areas were seen in 10 of the fish examined by autopsy (Fig. 1).

\section{Histopathology}

Of the 21 fish examined, focal necrosis of white muscle fibres was observed in 10 fish sampled early in the outbreak of disease. Larger areas of white muscle fibres were often completely replaced by an eosinophilic, hyaline mass, consistent with proteina- 


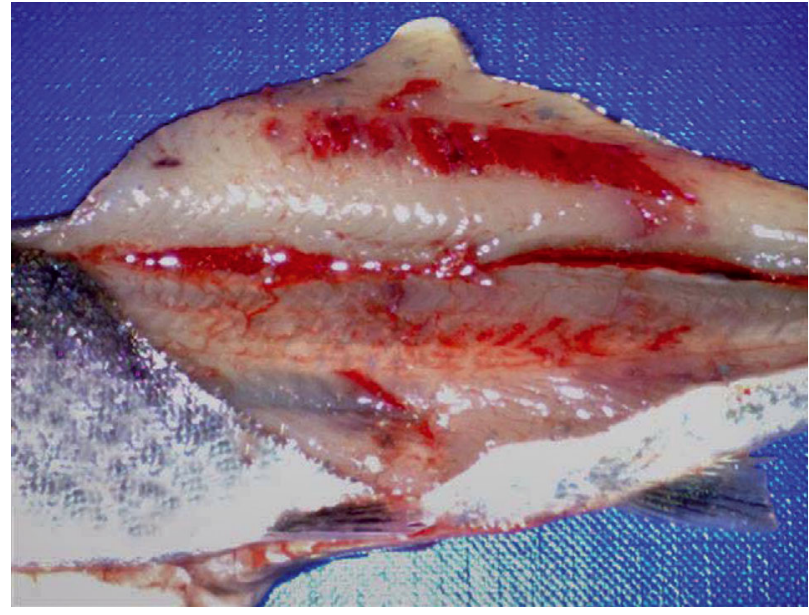

Fig. 1. Salmo salar. Extensive petecchiation and large haemorrhagic areas in skeletal muscle

ceous fluid. Erythrocytes and inflammatory cells were usually present within the necrotic areas (Fig. 2) and presumptive long slender bacterial rods were observed within the lesions (Fig. 3). The liquefactive necrosis appeared to be limited by the intermuscular connective tissue as adjacent myomeres were often unaffected. Bleeding in red skeletal muscle was observed in a few samples. In the heart, haemorrhage within the compact layer was noted in one-third of the fish examined.

In the majority of the kidney samples, necrosis of the tubular epithelium associated with basophilic material in the lumina was seen. Staining with von Kossa of sections from 4 fish confirmed the presence

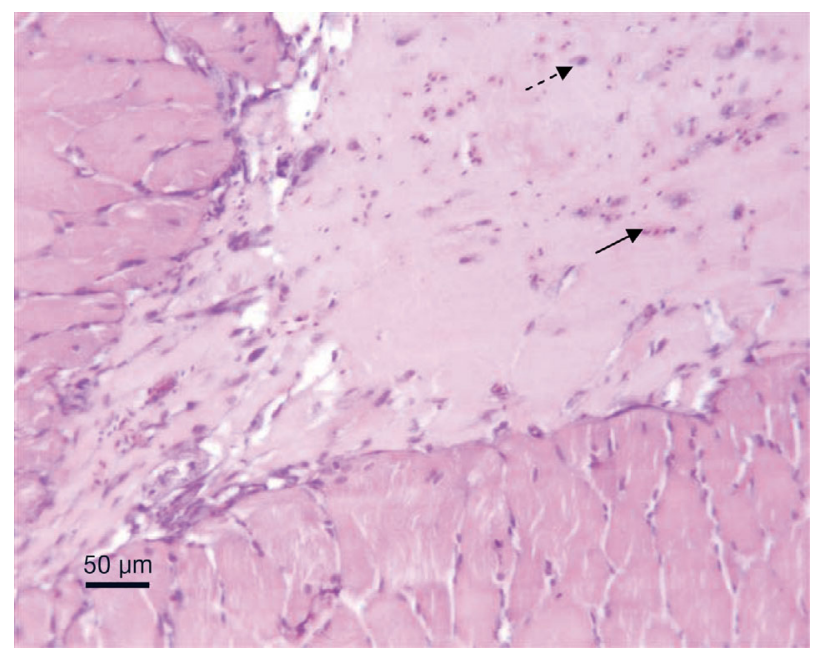

Fig. 2. Salmo salar. Erythrocytes (arrow) and inflammatory cells (dashed arrow) within necrotic areas in skeletal muscle. H\&E

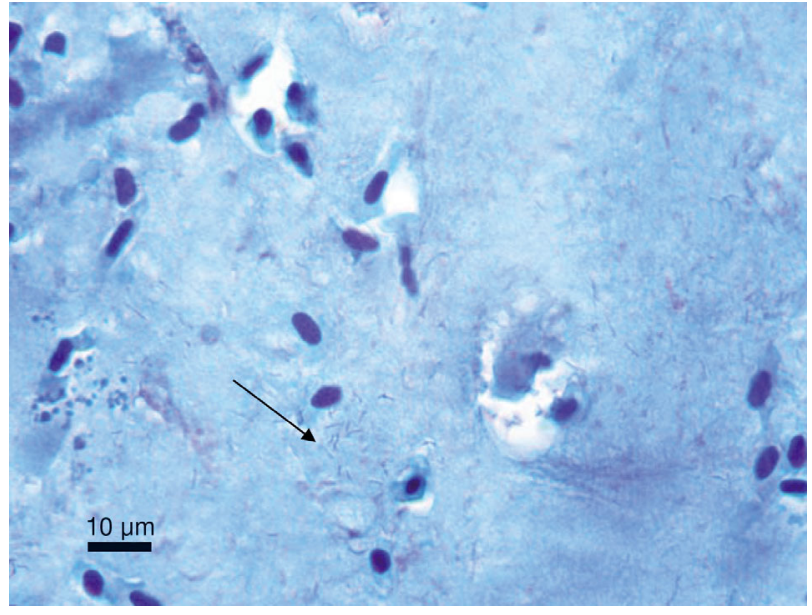

Fig. 3. Salmo salar. Long slender bacterial rods (arrow) in necrotic areas in skeletal muscle. May Grünwald Giemsa stain

of calcium in this material. In the gills, some hyperplasia of the respiratory epithelium was noted, and a moderate number of 'Costia' (Ichthyobodo necator) were observed in 10 of 15 fish examined.

The spleen border appeared intact in all sections examined.

\section{Immunohistochemistry}

In necrotic skeletal muscle, large areas of degenerated muscle fibers, proteinaceous fluid, and macrophage-like cells, stained positively in the 6 fish with necrotic myositis that were examined (Fig. 4); kidney melanomacrophages and sinusoidal endothelial cells stained positively in 4 of these fish. Positive staining of the glomerular endothelium was recorded in 1 fish (Fig. 5). Sections from fish sampled at the beginning of the outbreak showed more extensive staining compared to fish sampled $2 \mathrm{wk}$ later. No positive staining was recorded in sections from heart $(\mathrm{n}=5)$, brain $(n=2)$, spleen (1), liver (1) and eye (1).

\section{Bacteriology}

Samples from 14 fish that were cultured on AOA produced mixed cultures dominated by smooth, shiny, convex, yellow colonies; these cultures derived from the kidney in 10 fish, the spleen in 2 fish and the muscle in 3 fish, representing 11 individual fish. Selected isolates -3 from kidney and 2 from spleen, representing 4 individual fish (3 from the December 2008 sampling and 1 from January 2009) — were sub- 


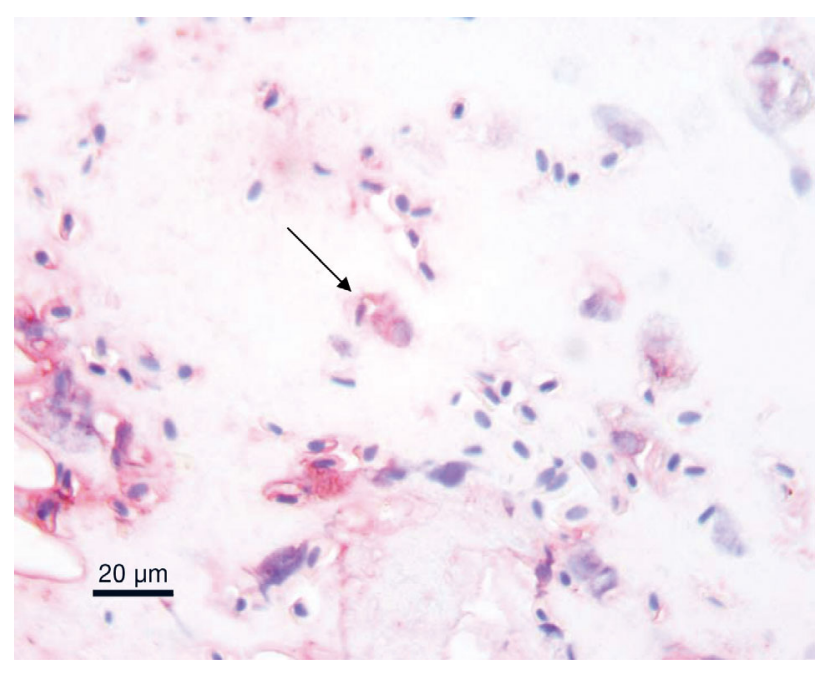

Fig. 4. Salmo salar. Skeletal muscle: positively stained areas of degenerated muscle fibres, proteinaceous fluid, and macrophage-like cells (arrow). Immunohistochemistry with polyclonal rabbit antiserum against Flavobacterium psychrophilum serotype Th

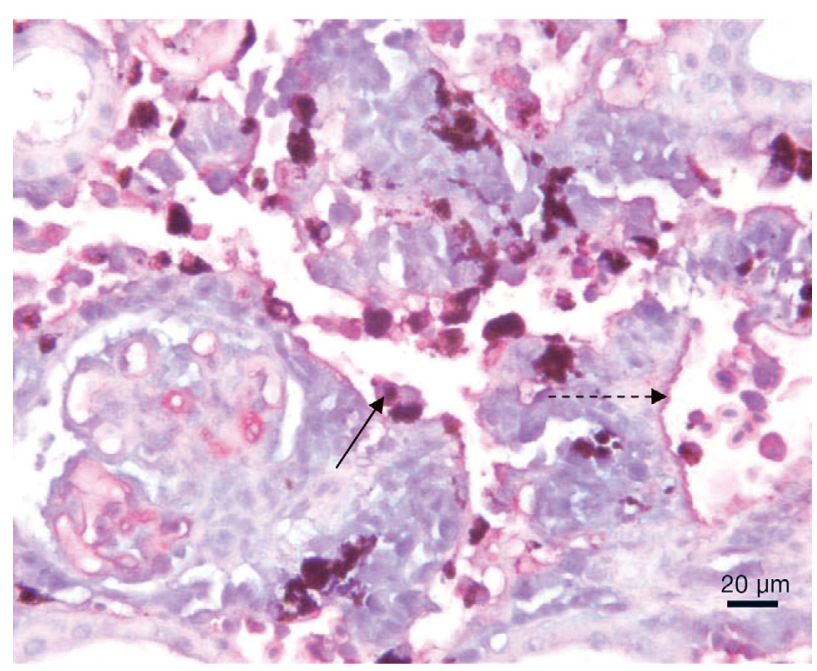

Fig. 5. Salmo salar. Kidney: positively stained melanomacrophages (arrow) and sinusoidal endothelial cells (dashed arrow) (immunohistochemistry)

jected to full characterisation and were identified as Flavobacterium psychrophilum by comparison with the type strain. Morphological and biochemical results are summarised in Tables $1,2 \& 3$.

Testing of yellow isolates on AOA from another 6 fish showed typical lack of growth on BA.

A sparse mixed bacterial flora was demonstrated on BA from the kidneys of 9 fish, while no growth was found from the remaining 5 fish. Strains tentatively identified as Rhodococcus sp. and Pseudomonas fluorescens were recovered as part of mixed cultures from one of the fish sampled. No other recognised potential fish pathogens were detected.

\section{Susceptibility of isolates to antibiotics}

The 4 isolates tested, and strains NCIMB $1947 \mathrm{~T}$ (ATCC 49418T) and CSF 259-93, displayed inhibition zones $>50 \mathrm{~mm}$ on AOA agar. Weak growth or no growth occurred on dilute $\mathrm{MH}$ agar.

\section{S rRNA gene sequence analysis}

All the sequences obtained from isolates NVIB 2008-50-3055-4 (1385 bases), NVIB 2008-50-3055-6 (1396 bases) and NVIB 2009-50-154-14 (1386 bases) displayed $100 \%$ identity with Flavobacterium psychrophilum (AM 398681.1).

\section{S rRNA alleles}

PCR products consistent in size (600 bp) with the 'CSF-only' allele (Ramsrud et al. 2007) were generated from all strains tested using primers A259-93 and AR259-93 (Fig. 6a, Table 4). Primers A49418 and AF49418 amplified products consistent in size (slightly under $300 \mathrm{bp}$ ) with the 'ATCC 49418T-only' allele (Ramsrud et al. 2007) from strains NVIB 200850-3055-4, NVIB 2008-50-3055-6 and NCIMB 1947 T (ATCC 49418T) (Fig. 6b, Table 4).

\section{Virology}

No viruses were detected by either PCR or cell culturing.

\section{DISCUSSION}

Flavobacterium psychrophilum is rarely reported as the causative agent of disease in Atlantic salmon under farming conditions (Schmidtke \& Carson 1995, Ekman et al. 1999, Valdebenito \& Avendaño-Herrera 2009), although high mortality has been induced in Atlantic salmon by intraperitoneal challenge (Ekman \& Norrgren 2003, Valdebenito \& Avendaño-Herrera 2009).

In the present study, septicaemia with Flavobacterium psychrophilum was diagnosed on the basis that the bacterium was cultured from internal organs and detected, indirectly, in pathological lesions in the majority of fish investigated. 
Table 1. Phenotypic characteristics of Flavobacterium psychrophilum in the present study. $\mathrm{n}=$ number of selected isolates; +: positive; (+): weakly positive; -: negative

\begin{tabular}{|lccc|}
\hline Test & F. psychrophilum & F. psychrophilum & F. psychrophilum \\
& NCIMB 1947T (ATCC 49418T) & CSF 259-93 & NVIB (n = 5) \\
\hline $\begin{array}{l}\text { Growth on Anacker \& } \\
\text { Ordal's agar (AOA) }\end{array}$ & Yellow-pigmented colonies & Yellow-pigmented colonies & Yellow-pigmented colonies \\
Growth on blood agar (BA) & - & - & - \\
Gram stain & Gram-negative & Gram-negative & Gram-negative \\
& long slender rods & long slender rods & long slender rods \\
Catalase activity & $(+)$ & ++ (+) \\
Oxidase activity & + & + & + \\
Congo red absorption & - & + & - \\
Flexirubin pigment production & + & + & + \\
Growth at $4{ }^{\circ} \mathrm{C}$ & + & - & + \\
Growth at $30^{\circ} \mathrm{C}$ & - & & + \\
\hline
\end{tabular}

Table 2. Hydrolysis of gelatin and elastin by strains of Flavobacterium psychrophilum. +: positive; -: negative

\begin{tabular}{|c|c|c|c|}
\hline Test & $\begin{array}{c}\text { F. psychrophilum } \\
\text { NCIMB 1947T (ATCC 49418T) }\end{array}$ & $\begin{array}{l}\text { F. psychrophilum } \\
\text { CSF 259-93 }\end{array}$ & $\begin{array}{l}\text { F. psychrophilum } \\
\text { NVIB }(\mathrm{n}=5)\end{array}$ \\
\hline Gelatin hydrolysis & + & - & + \\
\hline Elastin hydrolysis $(0.05 \%)$ & - & + & - \\
\hline Elastin hydrolysis $(0.5 \%)$ & - & + & - \\
\hline
\end{tabular}

Table 3. API ZYM tests on strains of Flavobacterium psychrophilum. All isolates tested positive for alkaline phosphatase, esterase (C4), esterase lipase (C8), lipase (C14), leucine arylamidase, acid phosphatase, naphthol-AS-BI-phosphohydrolase. All isolates tested negative for cystine arylamidase, trypsin, $\alpha$-chymotrypsin: $\alpha$-galactosidase, $\beta$-galactosidase, $\beta$-glucoronidase, $\alpha$-glucosidase, $\beta$-glucosidase, $N$-acetyl- $\beta$-glucosaminidase, $\alpha$-mannosidase and $\alpha$-fucosidase

\begin{tabular}{|lccc|}
\hline Enzyme & $\begin{array}{c}\text { F. psychrophilum } \\
\text { NCIMB 1947T (ATCC 49418T) }\end{array}$ & $\begin{array}{c}\text { F. psychrophilum } \\
\text { CSF 259-93 }\end{array}$ & F. psychrophilum NVIB (n = 5) \\
\hline $\begin{array}{l}\text { Negative control } \\
\text { Valine arylamidase }\end{array}$ & $\begin{array}{c}\text { Negative } \\
\text { Positive }\end{array}$ & $\begin{array}{c}\text { Negative } \\
\text { Positive }\end{array}$ & Positive $(\mathrm{n}=4) / \mathrm{neg}$ ative $(\mathrm{n}=1)$ \\
\hline
\end{tabular}

The histopathological findings in the present study resembled the description of necrotic myositis in rainbow trout from Canada caused by Flavobacterium psychrophilum (Lumsden et al. 1996). Necrotic myositis was characterised as loss of muscle fibre striation and oedema. Clear demarcarcation of necrotic areas from normal tissues was denoted by the fascial plane, and no red muscle fibre involvement was typical. These changes were consistent with the liquefactive necrosis of white skeletal muscle in Atlantic salmon observed in the present study.

In our study, the strains of Flavobacterium psychrophilum degraded gelatine. A crude extracellular preparation derived from F. psychrophilum, which showed a strong relationship between producing muscular necrosis and being able to degrade gelatin, has been proposed as a possible virulence factor (Ostland et al. 2000). Detection of only small numbers of bacterial cells within muscle sections may indicate that extracellular proteolytic activity was responsible for the changes observed. Maximum proteolytic activity has been observed in broth cultures of F. psychrophilum after 2 to 3 d (Bertolini et al. 1994), indicating that the proteolytic activity may occur some time after the initial phase of infection. This assumption is in agreement with our demonstration of antigen in kidney melanomacrophages - observations also made during experimental infections of rainbow trout (Evensen \& Lorenzen 1996).

Rangdale et al. (1999) described the histopathological findings such as loss of splenic border, fibrinous 
(a)

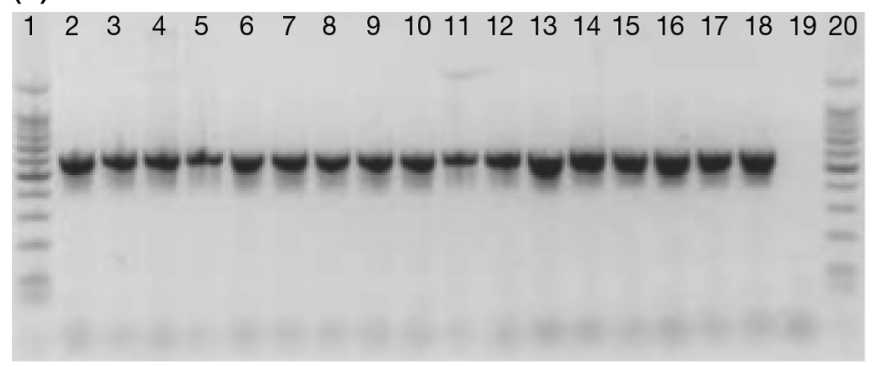

(b)

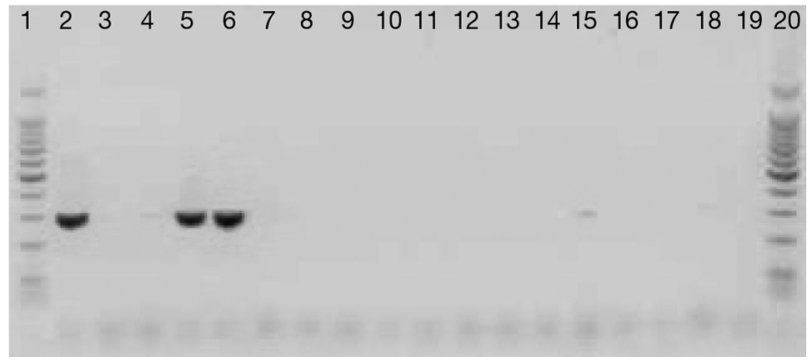

Fig. 6. Allele specific PCR products generated using (a) primers A259-93/AR259-93 and (b) primers A49418/AF49418. Lanes Lanes 1 \& 20: 100 bp ladder (Promega); Lane 2: NCIMB 1947T (ATCC 49418T); Lane 3: CSF 259-93; Lane 4: NVIB 2009-50154-14 (present study); Lane 5: 2008-50-3055-4 (present study); Lane 6: 2008-50-3055-6 (present study); Lanes 7 \& 8: rainbow trout 2004 Norway; Lane 9: rainbow trout 2007 Norway; Lanes 10-14: rainbow trout 2008 Norway; Lane 15: Atlantic salmon 1997 Norway; Lane 16: brown trout 1998 Norway; Lane 17: brown trout 1999 Norway; Lane 18: Atlantic salmon 2000 Norway; Lane 19: no template

inflammation, oedema, and the presence of long filamentous rods to be pathognomonic for RTFS in juvenile rainbow trout. In the present study, the spleen appeared not to be the target organ as no lesions were seen, no antigen was detected by immunohistochemistry, and bacteria were isolated only occasionally from the spleen.

Reports from the local fish health service suggest that the general health status of the fish involved in the present study was poorer than normal for this type of fish; we therefore suggest that underlying factors may also have contributed to the disease.

Histopathological examination revealed nephrocalcinosis in a large number of fish throughout the sampling period, a condition usually associated with high levels of $\mathrm{CO}_{2}$. The changes seen in the present study were, however, more severe than those observed under experimental conditions (Fivelstad et al. 1999). Similar pathological changes have been observed in association with haemorrhagic smolt syndrome (HSS) in Norway (Ole Bendik Dale, pers. com). HSS has been described from Norway and Scotland and is characterised by extreme acute haemorrhagic anaemia (Rodger \& Richards 1998), with bleeding in skeletal muscle and a compact layer of the cardiac ventricle combined with the presence of erythrocytes in the tubuli lumen of the kidneys. Although the histopathological findings in the heart, and some of the bleedings in the skeletal muscle in the present study, could resemble HSS, the presence of focal necrosis of white fibres in skeletal muscle and the absence of erythrocytes in the tubuli lumen of the kidney distinguished our findings from HSS. That the fish may also have been suffering from HSS (for which the aetiology is unknown), or that HSS acted as a contributory factor to the susceptibility of the fish to Flavobacterium psychrophilum, cannot, however, be discounted.
Bleeding in internal organs and skeletal muscle is a typical finding in rhabdovirus infections (VHSV and IHNV) in salmonids (Roberts 1989). Even though Atlantic salmon is not the most common host for

Table 4. PCR products generated using primers A49418 and AF49418 (ATCC 49418T), and primers A259-93 and AR25993 (CSF 259-93), in studies on strains of Flavobacterium psychrophilum isolated from a range of fish. 'Both' means that both alleles were present; 'CSF only' means that only the allele characteristic of strain CSF 259-93 was present. Host species are Atlantic salmon Salmo salar (L.), rainbow trout Oncorhynchus mykiss (Walbaum) and brown trout Salmo trutta (L.)

\begin{tabular}{|c|c|}
\hline Host species & $16 \mathrm{~S}$ allele \\
\hline NCIMB 1947T (ATCC 49418T) ${ }^{a}$ & Both \\
\hline CSF 259-93 & CSF only \\
\hline Atlantic salmon, NVIB 2009-50-154-14 & CSF only \\
\hline Atlantic salmon, NVIB 2008-50-3055-4 ${ }^{\mathrm{a}}$ & Both \\
\hline Atlantic salmon, NVIB 2008-50-3055-6 & Both \\
\hline Rainbow trout 2004 Norway $^{\mathrm{a}}$ & CSF only \\
\hline Rainbow trout 2004 Norway $^{\mathrm{a}}$ & CSF only \\
\hline Rainbow trout 2007 Norway $^{a}$ & CSF only \\
\hline Rainbow trout 2008 Norway $^{a}$ & CSF only \\
\hline Rainbow trout 2008 Norway $^{a}$ & CSF only \\
\hline Rainbow trout 2008 Norway $^{a}$ & CSF only \\
\hline Rainbow trout 2008 Norway $^{\mathrm{a}}$ & CSF only \\
\hline Rainbow trout 2008 Norway $^{a}$ & CSF only \\
\hline Rainbow trout 2008 Norway & CSF only \\
\hline Atlantic salmon 1997 Norway $^{a}$ & CSF only \\
\hline Brown trout 1999 Norway & CSF only \\
\hline Brown trout 1998 Norway $^{a}$ & CSF only \\
\hline Brown trout 1998 Norway & CSF only \\
\hline Brown trout 1999 Norway $^{a}$ & CSF only \\
\hline Atlantic salmon 2000 Norway $^{\mathrm{a}}$ & CSF only \\
\hline Atlantic salmon 1996 Norway & CSF only \\
\hline Atlantic salmon 1998 Norway & CSF only \\
\hline Atlantic salmon 1999 Norway & Both \\
\hline Atlantic salmon 2008 Norway & Both \\
\hline Atlantic salmon 2008 Norway & Both \\
\hline${ }^{\text {a}}$ Results shown in Fig. 6 & \\
\hline
\end{tabular}


these viruses, the severity of these diseases requires investigation of suspected cases. In this study the viruses were not detected.

The exact portal of entry of Flavobacterium psychrophilum to the host tissue remains unknown, but previous data have suggested that adhesion to gill tissues might be an important initial step in the pathogenesis (Nematollahi et al. 2003b) and there is experimental support for the hypothesis that ectoparasitic infection increases susceptibility of fish to other pathogens, such as bacteria (Bandilla et al. 2006). It can therefore be speculated that the costiasis diagnosed in our study may have contributed to the entry of F. psychrophilum.

Owing to delayed transfer to the sea, the smolts were revaccinated i.p during the winter at very low temperatures $\left(1.5\right.$ to $\left.3^{\circ} \mathrm{C}\right)$. Subsequent detection of a post-vaccination infection with Rhodococcus sp. in one fish suggests that vaccination conditions may not have been optimal (Olsen et al. 2006) and that the injection wound may also have provided a port of entry for Flavobacterium psychrophilum. The detection of Pseudomonas fluorescens in one fish may also suggest that this group of fish were prone to opportunistic infections.

A relationship has been proposed between the host species (the fish) and a specific lineage of Flavobacterium psychrophilum, i.e. between Pacific salmon and F. psychrophilum lineage I, and between rainbow trout and F. psychrophilum lineage II. Lineage II is exemplified by the well studied strain CSF 259-93, which has been shown to cause high mortality in a rainbow trout challenge model (LaFrentz et al. 2002). Lineage I is exemplified by strain NCIMB $1947 \mathrm{~T}$ (ATCC 49418T), which is unable to cause significant mortality in the same (rainbow trout) model (Cain et al. 2002). Strains of lineage I typically contain both alleles of the $16 \mathrm{~S}$ rRNA gene, i.e. the 2 alleles present in strain ATCC 49418T; strains of lineage II contain only the allele present in strain CSF 259-93. Strains isolated from Atlantic salmon are reported to be represented in both lineages (Soule et al. 2005a,b). PCR analysis of the limited number of isolates in the present study indicates that 2 different genotypes were present in the outbreak: the 2 isolates sampled early in the outbreak harboured both alleles (lineage I), while the single strain isolated later harboured only the allele from CSF 259-93 (lineage II). Analysis of strains isolated in Norway - other than those associated with the present outbreak - shows that strains from rainbow trout as well as those from brown trout belong to lineage II, while strains from Atlantic salmon are from both lineages (Fig. 6a,b \& Table 4).
The existence of an association between 16S rRNA allele type and virulence for particular host species is difficult to assess in the present case as the overall condition of the affected smolts was poor. The analysis does however provide information regarding the presence/distribution of these alleles in Norwegian aquaculture.

In this study, the strains of Flavobacterium psychrophilum did not degrade elastin. Although the degradation of elastin is considered to be a virulence factor in F. psychrophilum (Madsen \& Dalsgaard 1998, 2000), and has been correlated to strains in genetic lineage II (Soule et al 2005b), this trait was not reported in extracellular preparations of F. psychrophilum recorded from a case with necrotic myositis (Ostland et al. 2000).

Degradation of elastin and a lowered sensitivity towards quinolones were constant traits among strains involved in the Norwegian RTFS/BCWD epizootic of 2008 (Nilsen et al. 2011). The lack of these traits in our current isolates from Atlantic salmon differentiates them from the rainbow trout epizootic strains isolated in Norway in the same year.

This is, to our knowledge, the first described case of necrotic myositis in Atlantic salmon associated with Flavobacterium psychrophilum. It adds to the growing list of production-related diseases in salmon farming and supports a hypothesis that exaggerated stressful events during the smoltification period may predispose normally less-sensitive species to infection and septicaemia caused by F. psychrophilum. Our description gives further information about the relationships that may occur between hosts and the different lineages of F. psychrophilum.

Acknowledgements. This work was funded by the Norwegain Veterinary Institute. We gratefully acknowledge T. J. Welch, USDA_ARS-NCCCWA, USA for providing us with the CSF259-93 strain, and our colleagues: N.T. Martinussen for performing the 16S rRNA sequencing and T. Markussen for information relating to the virus examination.

\section{LITERATURE CITED}

Anacker RL, Ordal EJ (1959) Studies on the myxobacterium Chondrococcus columnaris. I. Serological typing. J Bacteriol 78:25-32

Bandilla M, Valtonen ET, Suomalainen LR, Aphalo PJ, Hakalahti T (2006) A link between ectoparasite infection and susceptibility to bacterial disease in rainbow trout. Int J Parasitol 36:987-991

Bernardet JF, Segers P, Vancanneyt M, Berthe F, Kersters K, Vandamme P (1996) Cutting a Gordian knot: emended classification and description of the genus Flavobacterium, emended description of the family Flavobacteri- 
aceae, and proposal of Flavobacterium hydatis nom nov (basonym, Cytophaga aquatilis Strohl and Tait 1978). Int J Syst Bacteriol 46:128-148

Bernardet JF, Nakagawa Y, Holmes B (2002) Proposed minimal standards for describing new taxa of the family Flavobacteriaceae and emended description of the family. Int J Syst Evol Microbiol 52:1049-1070

Bertolini JM, Wakabaysahi H, Watral VG, Whipple MJ, Rohovec JS (1994) Electrophoretic detection of proteases from selected strains of Flexibacter psychrophilus and assessment of their variability. J Aquat Anim Health 6: 224-233

Borg AF (1948) Studies on myxobacteria asossciated with diseases in salmonid fishes. PhD thesis, University of Washington, Seattle, WA

Borg AF (1960) Studies on myxobacteria associated with diseases in salmonid fishes (Wildlife Disease no. 8). American Association for the Advancement of Science, Washington, DC

Cain KD, Grabowski L, LaPatra E (2002) Separation and comparison of proteins from virulent and nonvirulent strains of the fish pathogen Flavobacterium psychrophilum, using a 2-D electrophoretic approach. Bio-Rad technical note 2670. Bio-Rad, Richmond, CA

Clinical and Laboratory Standards Institute (2006) Methods for antimicrobial disk susceptibility testing of bacteria isolated from aquatic animals. Approved guideline. CLSI document M42-A [1-56238-611-5]. Clinical and Laboratory Standards Institute, Wayne, PA

Davis HS (1946) Care and diseases of trout. United States Fish and Wildlife Service research report 12. Washington, DC

> Ekman E, Norrgren L (2003) Pathology and immunohistochemistry in three species of salmonids after experimental infection with Flavobacterium psychrophilum. J Fish Dis 26:529-538

Ekman E, Borjeson H, Johansson N (1999) Flavobacterium psychrophilum in Baltic salmon Salmo salar brood fish and their offspring. Dis Aquat Org 37:159-163

Evensen $\varnothing$, Lorenzen E (1996) An immunohistochemical study of Flexibacter psychrophilus infection in experimentally and naturally infected rainbow trout (Oncorhynchus mykiss) fry. Dis Aquat Org 25:53-61

Fivelstad S, Olsen AB, Kloften H, Ski H, Stefansson S (1999) Effects of carbon dioxide on Atlantic salmon (Salmo salar L.) smolts at constant $\mathrm{pH}$ in bicarbonate-rich freshwater. Aquaculture 178:171-187

Holt RA, Rohovec JS, Fryer JL (1993) Bacterial coldwater disease. In: Inglis V, Roberts RJ, Bromage NR (eds) Bacterial diseases of fish. Blackwell Scientific Publications, Oxford, p 3-22

Johansen R, Kongtorp RT, Bornø G, Skjelstad HR and others (2009) Farmed fish health report. http://www.vetinst.no/ eng/Research/Publications/Fish-Health-Report/FarmedFish-Health-Report

> LaFrentz BR, LaPatra SE, Jones GR, Cain KD (2002) Characterization of serum and mucosal antibody responses and relative per cent survival in rainbow trout Oncorhynchus mykiss (Walbaum) following immunization and challenge with Flavobacterium psychrophilum. J Fish Dis 25:703-713

Lorenzen E, Carstensen B, Olesen NJ (1999) Inter-laboratory comparison of cell lines for susceptibility to three viruses: VHSV, IHNV and IPNV. Dis Aquat Org 37: 81-88
Lumsden JS, Ostland VE, Ferguson HW (1996) Necrotic myositis in cage-cultured rainbow trout Oncorhynchus mykiss (Walbaum) caused by Flexibacter psychrophilus. J Fish Dis 19:113-119

Madsen L, Dalsgaard I (1998) Characterization of Flavobacterium psychrophilum; comparison of proteolytic activity and virulence of strains isolated form rainbow trout Oncorhynchus mykiss. In: Barnes AC, Davidson GA, Hiney MP, McIntosh D (eds) Methodology in fish diseases research. Fisheries Research Services, Aberdeen, p 45-52

> Madsen L, Dalsgaard I (2000) Comparative studies of Danish Flavobacterium psychrophilum isolates: ribotypes, plasmid profiles, serotypes and virulence. J Fish Dis 23:211-218

Matejusova I, McKay P, McBeath AJA, Collet B, Snow M (2008) Development of a sensitive and controlled realtime RT-PCR assay for viral haemorrhagic septicaemia virus (VHSV) in marine salmonid aquaculture. Dis Aquat Org 80:137-144

Nematollahi A, Decostere A, Pasmans F, Haesebrouck F (2003a) Flavobacterium psychrophilum infections in salmonid fish. J Fish Dis 26:563-574

Nematollahi A, Decostere A, Pasmans F, Ducatelle R, Haesebrouck F (2003b) Adhesion of high- and low-virulence Flavobacterium psychrophilum strains to isolated gill arches of rainbow trout Oncorhynchus mykiss. Dis Aquat Org 55:101-107

Nilsen $\mathrm{H}$, Olsen AB, Vaagnes $\varnothing$, Hellberg $\mathrm{H}$, Bottolfsen $\mathrm{K}$, Skjelstad H, Colquhoun DJ (2011) Systemic Flavobacterium psychrophilum infection in rainbow trout Oncorhynchus mykiss (Walbaum) farmed in fresh and brackish water in Norway. J Fish Dis 34:403-408

Olsen AB, Birkbeck TH, Nilsen HK, MacPherson HL and others (2006) Vaccine-associated systemic Rhodococcus erythropolis infection in farmed Atlantic salmon Salmo salar. Dis Aquat Org 72:9-17

> Ostland VE, McGrogan DG, Ferguson HW (1997) Cephalic osteochondritis and necrotic scleritis in intensively reared salmonids associated with Flexibacter psychrophilus. J Fish Dis 20:443-451

> Ostland VE, Byrne PJ, Hoover G, Ferguson HW (2000) Necrotic myositis of rainbow trout Oncorhynchus mykiss (Walbaum): proteolytic characteristics of a crude extracellular preparation from Flavobacterium psychrophilum. J Fish Dis 23:329-336

Prophet EB, Mills B, Arrington JB, Sobin LH (1994) Pigments and minerals. In: Prophet EB, Mills B, Arrington JB, Sobin LH (eds) Laboratory methods in histotechnology. American Registry of Pathology, Washington, DC, p 197

> Ramsrud AL, LaFrentz SA, LaFrentz BR, Cain KD, Call DR (2007) Differentiating 16S rRNA alleles of Flavobacterium psychrophilum using a simple PCR assay. J Fish Dis 30:175-180

> Rangdale RE, Richards RH, Alderman DJ (1999) Histopathological and electron microscopical observations on rainbow trout fry syndrome. Vet Rec 144:251-254

Roberts RJ (1989) The virology of teleosts. In: Roberts RJ (ed) Fish pathology. Baillière Tindall, London, p 173-241

> Rodger HD, Richards RH (1998) Haemorrhagic smolt syndrome: a severe anaemic condition in farmed salmon in Scotland. Vet Rec 142:538-541

Schmidtke LM, Carson J (1995) Characteristics of Flexibacter psychrophilus isolated from Atlantic salmon in Australia. Dis Aquat Org 21:157-161 
Soule M, Cain K, LaFrentz S, Call DR (2005a) Combining suppression subtractive hybridization and microarrays to map the intraspecies phylogeny of Flavobacterium psychrophilum. Infect Immun 73:3799-3802

Soule M, LaFrentz S, Cain K, LaPatra S, Call DR (2005b) Polymorphisms in 16S rRNA genes of Flavobacterium psychrophilum correlate with elastin hydrolysis and tetracycline resistance. Dis Aquat Org 65:

Editorial responsibility: David Bruno,

Aberdeen, UK
$209-216$

Valdebenito S, Avendaño-Herrera R (2009) Phenotypic, serological and genetic characterization of Flavobacterium psychophilum strains isolated from salmonids in Chile. J Fish Dis 32:321-333

Weisburg WG, Barns SM, Pelletier DA, Lane DJ (1991) 16S Ribosomal DNA amplification for phylogenetic study. J Bacteriol 173:697-703

Submitted: May 3, 2010; Accepted: June 28, 2011

Proofs received from author(s): October 18, 2011 